University of Windsor

Scholarship at UWindsor

May 14th, 9:00 AM - May 17th, 5:00 PM

\title{
Truth, Thinking, Testimony and Trust: Alvin Goldman on Epistemology and Education
}

\author{
Harvey Siegel \\ University of Miami
}

Follow this and additional works at: https://scholar.uwindsor.ca/ossaarchive

Part of the Philosophy Commons

Siegel, Harvey, "Truth, Thinking, Testimony and Trust: Alvin Goldman on Epistemology and Education" (2003). OSSA Conference Archive. 82.

https://scholar.uwindsor.ca/ossaarchive/OSSA5/papersandcommentaries/82

This Paper is brought to you for free and open access by the Conferences and Conference Proceedings at Scholarship at UWindsor. It has been accepted for inclusion in OSSA Conference Archive by an authorized conference organizer of Scholarship at UWindsor. For more information, please contact scholarship@uwindsor.ca. 
Title: $\quad$ Truth, Thinking, Testimony and Trust: Alvin Goldman on Epistemology and Education

Author: $\quad$ Harvey Siegel

(C) 2003 Harvey Siegel

Despite both the central importance of education in the work of many of the major figures of the Western philosophical tradition, and the deep philosophical issues raised by the practice of education, philosophy of education has not always been regarded by contemporary philosophers as an important, or even a legitimate, area of philosophy. - As he has done on many other philosophical fronts, Alvin Goldman has challenged this conventional view by paying considerable attention to education in his recent work on social epistemology. Especially noteworthy are his views of the place of truth, and of testimony and trust, in an adequate characterization of the aims of teaching and of education.

Goldman's aim, in Knowledge in a Social World (1999)_2 ${ }^{2}$, is nothing less than the articulation and establishment of a new discipline. He calls his proposed discipline veritistic (i.e. truth-linked) social epistemology (VSE): the study of the social processes which facilitate or inhibit our collective efforts to obtain or increase knowledge. Knowledge is understood, in turn, in the 'weak' sense of true belief. VSE is motivated by the truth of Aristotle's dictum that "All men by nature desire to know" (3) - that is, desire accurate or true information, in contrast with misinformation (false belief) and lack of information (ignorance) - both for its own sake, and to facilitate our other practical concerns. Social epistemology is social in its focus on social paths to knowledge and the practices of social groups in the pursuit of knowledge. Truth, though, is the key notion of VSE, and its key question is: which social processes help (or hinder) us in the pursuit of knowledge, i.e. true belief? In the book he examines a wide range of social practices both 'generic' practices involving testimony, argumentation, communication, and speech regulation, and practices in the specific domains of science, law, democracy, and education always focusing on the extent to which these practices conduce to true belief. While Goldman's entire discussion is worthy of attention, I here restrict myself to his treatment of education.

Goldman's veritistic approach to social epistemology gives pride of place to truth as the fundamental aim, and the highest epistemic value, of education. Equally noteworthy is his emphasis on the social dimensions of educational epistemology, in particular the roles of testimony and trust in appropriate teacher-student interactions. I agree with Goldman on many points, in particular his (broad) embrace of veritism and his critique of 'veriphobia,' his criticism of the postmodern rejection of truth, his stress on the compatibility of veritism and the centrality to education of the aim of fostering critical thinking, his thesis that (non-'radical' or -degenerate forms of) multiculturalism is (are) compatible with (Goldman's non-essentialist brand of) veritistic epistemology, and his insistence that both truth and expertise are relevant to curricular decisions and his discussion of ways in which non-experts can accurately appraise expertise in curricular contexts. Despite all this agreement, there are I think two points on which Goldman's account can be improved: the relation of veritism to critical thinking, and the roles of testimony 
and trust in education and its epistemology. I address these two in what follows.

\section{Truth and Thinking}

\section{Goldman's chapter on education begins with the declaration that}

The fundamental aim of education, like that of science, is the promotion of knowledge [i.e. true belief]. Whereas science seeks knowledge that is new for humankind, education seeks knowledge that is new for individual learners. Education pursues this mission in several ways: by organizing and transmitting pre-existing knowledge, by creating incentives and environments to encourage learning, and by shaping skills and techniques that facilitate autonomous learning and steer inquiry toward truth. This veritistic conception is a traditional picture of what education is all about, one aligned with an "Enlightenment" conception of epistemology. Despite popular critiques of the Enlightenment view, the veritistic model is still the best available, one that fits all stages of education from lowest to highest. Admittedly, knowledge and knowledge-dedicated skills are not the sole educational goals. Education in studio art or music performance, for example, is not primarily concerned with propositional knowledge or with skills for acquiring propositional knowledge. But propositional knowledge is, nonetheless, education's most pervasive and characteristic goal (349).

Like Goldman, I too defend an 'Enlightenment' conception of epistemology, and have challenged popular but in my view misguided criticisms of it (Siegel 1997, 1999). So ours is an in-house dispute, carried on within the 'Enlightenment' camp. My counterclaim is that it is not truth, but rather rational belief, that is "the crucial epistemic aim" (363) of education; and that the fostering of the skills, abilities, and dispositions and habits of mind constitutive of the critical thinker/rational person ${ }^{3}$ - in particular, those involved in reason assessment - is educationally fundamental (Siegel 198̄8, 1997). Following Goldman, I focus here primarily on the epistemic aim. So the issue before us is: is 'the crucial epistemic aim' of education that of truth, or rational belief? Are our educational efforts (in so far as they concern student belief) rightly regarded as aiming, fundamentally, at the production of true beliefs, or rather rational beliefs, in our students?

On the view of 'the crucial epistemic aim' that I favor, education should strive to foster, not knowledge or true belief, but rather the skills, abilities and dispositions constitutive of - and so belief generated and sustained by - critical thinking. Goldman considers this alternative to his preferred, veritistic view, i.e. the position that "the crucial epistemic aim is not true belief, but [rather] warranted, justified, or rational belief” (362-3, emphasis in original). He does not challenge the educational value of critical thinking. He argues, rather, that it must be seen not as "an epistemic end in itself," but rather as "a useful means to the fundamental epistemic end of true belief” (363, see also Goldman 1998, pp. 445-6). As Goldman articulates his view:

I am very sympathetic to some form of critical-thinking approach, but this is not incompatible with veritism. Unlike many critical-thinking advocates (such as Siegel), I do not see critical thinking as an epistemic end in itself. Critical thinking or rational inference is a useful means to the fundamental epistemic end of true belief. It is a crucial 
skill that should be developed in cognizers to help them attain true belief. Acknowledging an important role for critical thinking in education, then, is no admission of any flaw in veritism. It can be seen as merely an elaboration of veritism's implications (363, emphasis in original).

Goldman and I are agreed that both the fostering of the skills and abilities of critical thinking, and the production of true belief, are legitimate educational aims. And, indeed, Goldman's later, extended comments (366) concerning the educational importance of critical thinking are sufficiently forceful to warm the hearts of its advocates. Despite this agreement, however, questions remain. Is Goldman right that the former is of merely instrumental value, and that only the latter is rightly regarded as 'the fundamental epistemic end' of education? Is education in this respect like the "great variety of human endeavors [that] are dedicated, quite properly and understandably, to the discovery and dissemination of truths"? (Goldman 1998, p. 439) Is it true that "the fundamental aim of education, that is, of schooling systems at all levels, is to provide students with knowledge [i.e. true belief] and to develop intellectual skills that improve their knowledge-acquiring abilities”? (ibid.) $)^{4}$ If true, does this place educational activities aimed at enhancing critical thinking "on a deeper foundation" than it might otherwise have? (Goldman 1998, p. 445) I argue next that all these questions should be answered in the negative.

Let us agree with Goldman that, viewed from the perspective of social epistemology, veritism dictates that "educators should try to train students in truth-acquiring methods" (351). Presuming for the sake of argument some aspects of Goldman's reliabilism, it should be noted that many of our most reliable methods, e.g. observation of middle-sized objects under normal circumstances, leave only little room for educational enhancement: Johnny doesn't need much education to reliably observe (e.g.) the tree outside the classroom window, or even to reliably identify it as an oak. Still, there are reliable methods - in particular, those relevant to reasoning and argumentation (evaluating causal claims, drawing deductive and inductive inferences, estimating probabilities, evaluating inferences drawn by others, etc.) - that do seem to be the proper province of education. And indeed, both veritists and advocates of critical thinking focus on just such matters in their respective educational agendas. Nevertheless, I respectfully disagree with Goldman's basic claim that the "fundamental aim of education....is the promotion of knowledge" in the weak sense, i.e. true belief (349).

1. The first reason for my disagreement is the virtually total unavailability of methods which infallibly yield truths. Even for our most reliable methods, e.g. simple observation or deduction, truth is not the guaranteed result of our inquiries: too often either we err, or the universe fails to cooperate. Goldman of course readily acknowledges the fallibility of even our most reliable methods. Given that, typically, neither we nor our students infallibly know what is true, what we want (as veritism admits) is that students become able to seek, find, and competently recognize/identify the truth, to the fullest extent that our fallible methods and abilities allow. If so, the basic educational aim should be seen not as the production of true belief, per se, but rather as that of enabling students to judge wisely the truth, and this sort of judgment just is judgment based on the proper evaluation of reasons. Students should be enabled "not to judge the truth infallibly but to estimate the truth responsibly" (Scheffler 1965, p. 54), and that is a matter of rational inquiry and judgment. Consequently, critical thinking, and the pursuit of justified belief, is educationally fundamental, even if Goldman is right that truth is more fundamental than warrant, justification or rationality in the broader context of social- 
epistemological theory. The primary epistemic aim of education is not true belief, as Goldman claims, but rather the development of students who judge or estimate the truth skillfully and well, and this is a matter of critical thinking.

It may be responded ${ }^{5}$ that an appeal to fallibilism cannot justify a preference for regarding critical thinking rather than the promotion of true belief as the primary aim of education, since the methods of critical thinking are also fallible. The last point is true, but does not challenge the mentioned preference. It is because virtually no methods are infallible - neither those endorsed by reliabilism in particular or social epistemology more generally, nor those constitutive of critical thinking - that it is a mistake to regard the basic aim of education as the promotion of truth. While we aim at truth, we determine truth value by engaging in inquiry and assessing justificatory status: is there good reason to regard the proposition in question as true? Even Goldman acknowledges the point: "The usual route to true belief, of course, is to obtain some kind of evidence that points to the true proposition and away from its rivals" (24). If this is correct, the basic aim of education must be the development in students of the ability to assess truth status skillfully and accurately. It is only through such assessment that students can hope, and be expected, to reach and recognize the truth they seek. (More on this below.)

To state this point more succinctly: the pre-eminent aim of education cannot be the learning of truths simpliciter, given fallibilism; it must rather be the learning of what we identify at a given time as true. That is, it is our best estimate of truth that is key - and that is what critical thinking is all about. Consequently, even if our fundamental epistemic aim is true belief, our inability to acquire it directly requires that we pursue it by way of critical thinking/evidential reasoning, and it is therefore the latter which is the proper (epistemic) focus of education.

So far, Goldman can happily agree, since, however essential to the acquiring of true beliefs critical thinking might be, I have not said anything that suggests that it is a mistake to regard critical thinking as anything other than merely instrumentally valuable with respect to the achievement of that end. Let us then continue.

2. Which is the educational success: a student settling on a true belief but without justification, or a student settling on a justified belief (through the exercise of critical thinking) that turns out to be false? The answer seems obvious: as educators we regard the student who estimates the truth responsibly, but is mistaken, more highly epistemically than the student who hits upon a lucky true belief. We evaluate educational systems, and our own efforts as teachers, not in terms of student acquisition of truth, but rather in justificatory terms - i.e. in terms of the degree to which students master relevant material, and utilize it in the formulation of justified belief. ${ }^{6}$ The conclusion I draw from this is, again, that from the educational point of view, it is justification rather than truth which is epistemically fundamental. Note that this is completely compatible with the veritist's point that the value of justification lies in its tie to truth.

Nevertheless, it suggests that critical thinking, and justification more generally, has educational and epistemic value independently of its serving as a means to true belief.

3. As we have seen, Goldman denies that "critical thinking [is] an epistemic end in itself. Critical thinking or rational inference is [rather] a useful means to the fundamental epistemic end of true belief. It is a crucial skill that should be developed in cognizers to help them attain true belief" (363). In contrast, many advocates of critical thinking hold both that it is not solely a skill or set of skills, and that it is also valuable independently of the (admitted) fundamental epistemic end of true belief. That is, critical thinking is not only instrumentally valuable in virtue of its tie to truth; it is also intrinsically valuable in virtue of its multifaceted relationships to rationality, justification, responsible belief, and even character (Cf. Siegel 1988, 1997). 
I'm not sure how big a disagreement this is. I happily admit that we rightly value critical thinking (and justification more generally) because of its tie to truth. But I do not see why we should value it only instrumentally, and not also independently of that tie, for the following reasons.

(a) Given the elusiveness of truth and the difficulty of finding it, justification-conferring critical thinking skills and abilities are central to the lives of truth-seeking epistemic agents, and so to their education. Even when their exercise of critical thinking fails to result in true belief (for example, because of incomplete or misleading evidence), their doxastic situation is preferable to that which would have resulted from the failure to think critically. This must be granted by any epistemologist who grants, as Goldman does, the normative character of justification in particular, and epistemology more generally (e.g. 24; Goldman 1986, pp. 2-3, 2026, 58, passim).

(b) As already noted, we don't in general have 'direct access' to truth; if we want to have true beliefs, we typically have no option but to reason evidentially. That is, we have to judge whether $p$ is true, and, if we're rational, we do this on the basis of reasons and evidence. This is true generally; it is especially important in the context of education: what we want is for students to judge the truth competently, and that means being able and disposed to reason well, evaluate evidence well, search for evidence well, construct and evaluate arguments well, etc. That is, we want education to foster students' critical thinking. This point deserves further development.

Because we lack direct access to truth, we have no choice but to approach truth by way of justification. The point is made by many contemporary epistemologists. As Nicholas Rescher puts it, "we have no way of getting at the facts directly, without the epistemic detour of securing grounds and reasons for them” (Rescher 1988, p. 43). Roderick Firth puts it as follows: "To the extent that we are rational, each of us decides at any time $t$ whether a belief is true, in precisely the same way that we would decide at $t$ whether we ourselves are, or would be, warranted at $t$ in having that belief” (Firth 1981, p. 19). As Laurence BonJour articulates and explains the point:

What makes us cognitive beings at all is our capacity for belief, and the goal of our distinctively cognitive endeavors is truth: we want our beliefs to correctly and accurately depict the world. If truth were somehow immediately and unproblematically accessible...so that one could in all cases opt simply to believe the truth, then the concept of justification would be of little significance and would play no independent role in cognition. But this epistemically ideal situation is quite obviously not the one in which we find ourselves. We have no such immediate and unproblematic access to truth, and it is for this reason that justification comes into the picture” (BonJour 1985, p. 7).

Such citations could by multiplied indefinitely. Tellingly, as we have already seen, Goldman himself makes this point: "The usual route to true belief, of course, is to obtain some kind of evidence that points to the true proposition and away from rivals” (24).

If this point is correct, in an important sense the truth drops out as an (epistemic) educational end: as educators, we want students to be critical thinkers, even when (because of misleading evidence, etc.) being so directs them away from truth. If this is right - that is, if it is right that we want students to engage in critical thinking even when doing so directs them away from the truth - critical thinking is of fundamental educational importance independently of truth. Education is primarily concerned to foster responsible believing and justified belief, which 
are only fallibly tied to truth. Thus, from the educational point of view, it is critical thinking which is fundamental, not truth.

Now, so far as I can see, the veritist can and should grant (a), in which case our disagreement concerns only (b). And that disagreement too seems to me minimal, given Goldman's agreement with the claim that our main reliable access to truth is through the portal of evidence/justification. I hope that Goldman can acknowledge the intrinsic (and not only the instrumental) value of critical thinking, and moreover its centrality to an overarching view of the aims of education. I think that he can do this without in any way compromising his commitment to veritism, since, as he himself emphasizes, the two aims - true belief, and critical thinking - are compatible.

We are agreed on this compatibility, and also on the educational value of each. My challenge is simply to Goldman's claim that critical thinking is of value solely in virtue of its role as a means to true belief; that is, that critical thinking is of solely instrumental value. On the contrary, it is also epistemically valuable independently of its instrumental tie to truth.

There are, moreover, additional reasons for regarding critical thinking, rather than truth, as educationally fundamental.

(c) We want students (and persons generally) to be reflective about their beliefs - to question their beliefs; to ask themselves: 'I (don’t) believe that $p$, but should I?' - and that education should help to foster this reflectiveness.- - Such reflection takes our fallibility seriously. It is clear that it can in turn be justified in veritistic terms - we value it because it can help to weed out error and increase true belief. But it enjoys an integrity and non-instrumental value of its own. That a critical thinker is able and disposed to revise or correct her thought or action in light of criticism (by herself or others) is not just a mark of her ability to identify truth; it is also an important dimension of her character. I turn to this next.

(d) Education is not merely a propositional matter; it aims at far more than fostering belief, whether true or rational. It is also fundamentally concerned with fostering dispositions in students, and, more generally, with helping students to become particular sorts of persons, with particular traits of character. Of course there are many different sorts of dispositions and character traits which might be thought worthy of fostering; I will not here address the panoply of candidate dispositions and traits, although I think a strong case can be made for those associated with critical thinking (Siegel 1988, chs. 2-3). The important point in this context is that veritism misses this entire dimension of education. Even if Goldman is right that, so far as belief is concerned, true belief is the basic educational aim, and rational belief merely instrumentally valuable in its service to truth, it remains nonetheless that we want students to emerge from their education with more than a host of true beliefs and the skills required to capture more. We want them not only also to be reflective, but in addition to be disposed to base their beliefs upon reasons and evidence, to seek out reasons for candidate beliefs, to be open to both others' criticisms of their own beliefs and to others' contrary beliefs, to take seriously the reasons and points of view of others, and so on. While these can be seen by the veritist to be in service to the truth, and so compatible with veritism - which they are - it is important to see that these also have moral dimensions (involving respect for others, intellectual modesty and humility, etc.), and that these latter dispositions and traits can be justified independently of considerations of truth. Veritism's view of education is thus overly narrow in a way that the contrary view, that takes critical thinking to be educationally fundamental, is not. $\stackrel{-}{-}$

(e) A central dimension of critical thinking is its interrelationship with autonomy: in so far as a student is a critical thinker, she enjoys an independence of judgment that is of 
fundamental educational importance. That is, she is free to judge (and act) independently of external constraint, in accordance with her own reasoned appraisal of the matter at hand. As Israel Scheffler puts the point, we must "surrender the idea of shaping or molding the mind of the pupil. The function of education...is rather to liberate the mind, strengthen its critical powers, [and] inform it with knowledge and the capacity for independent inquiry” (Scheffler 1989, p. 139). That is, a key aim of education is that of freeing students from the myriad of cognitive shackles that a myriad of sources - including their education - might place upon them. The idea that education aims at liberating the mind and fostering students' autonomy is a central dimension of the 'Enlightenment' view that Goldman takes himself to be defending; but its desirability can be neither fully explained nor fully justified in veritistic terms. The explanatory and justificatory connections between autonomy, liberation and critical thinking, on the other hand, are straightforward (Siegel 1988).

The points just made (c-e) take for granted a set of 'Enlightenment' values that can be and have been challenged from a variety of 'post-Enlightenment' perspectives; both Goldman (1999) and I $(1977,1999)$ have responded to some of these challenges. Of course our responses might be defective in various ways. But the issue on the table here concerns not these broad issues, but rather whether, from within the Enlightenment perspective we share, critical thinking is rightly seen as valuable merely instrumentally, in virtue of its tie to truth, or is rather better seen as of value also independently of that tie. I hope that the considerations just rehearsed make it clear that the former view is simply too narrow; that critical thinking's value, both cognitively but especially educationally, extends far beyond that tie. To link the value of critical thinking wholly to its instrumental tie to truth is unduly to narrow its scope. That value, even when considered from a narrowly epistemic perspective, exceeds critical thinking's fallible tendency to produce true belief. When a broader view of education is considered - one which takes into account education's central concern with the fostering of dispositions, the enhancement of autonomy, and the development of character - the narrowness of veritism's focus on true belief as the fundamental aim of education is manifest. I am happy to grant Goldman's claim that critical thinking is instrumentally valuable in virtue of its role in the production of true belief. Nevertheless, if the arguments above have merit, such thinking has epistemic value independently of its tie to truth. Moreover, it is valuable also in light of its place in the enhancement of autonomy and the fostering of dispositions and traits of character - matters which are themselves educationally fundamental, but which extend far beyond education's concern with the promotion of true belief. In these respects, then, it is critical or rational thinking, rather than truth, that is educationally fundamental.

\section{Testimony and Trust}

Goldman connects his argument that truth (rather than critical thinking) is the fundamental aim of education with his discussion of the roles of testimony and trust in educational contexts. His basic claim is that a thorough-going commitment to critical thinking is both educationally counter-productive and epistemologically suspect:

A good bit of actual teaching consists of teachers "telling" things to students, that is, making statements or assertions without supporting reasons, evidence, or argument. Should students be expected to believe these statements? ... Not only students but all 
sorts of hearers encounter unsupported assertions or "testimony" from speakers. Under what circumstances are they justified in believing these statements? (363-4)

Goldman here links the problem of justified belief in teachers' testimonial assertions to the general problem of the epistemology of testimony, and suggests that it would be both educationally counter-productive to hold that students ought not to accept their teachers' testimonial assertions, and epistemologically dubious to hold that students would not be justified in believing those assertions. He then argues - contrary to the view (associated with critical thinking) that students ought to believe only those teacher testimonial pronouncements which can be justified by testimony-independent good reasons, which Goldman labels '(GR)' - that students sometimes ought to believe such pronouncements despite the absence of justifying reasons/evidence. The just-cited passage continues:

The good reasons approach would presumably answer with something like the following principle:

(GR) A hearer is never justified in believing what a speaker (baldly) asserts unless the hearer has good, independent reasons to trust the speaker on that occasion (364).

Goldman proceeds to criticize (GR). His criticism depends partly on his doubts about 'reductionism,' according to which “a hearer is justified in believing speakers' assertions if and only if the hearer has good reasons to trust the speaker, reasons that do not ultimately rest on testimony itself but instead rest wholly on perception, memory and so forth" (364; see also 12630; 1998, pp. 447-9). But Goldman does not declare himself on the ultimate non-acceptability of reductionism; although clearly inclined toward non-reductionism, he is uncharacteristically cagey in his unwillingness to take a definite stand on the matter (127; 1998, pp. 447-9). His argument rather has the form: if reductionism is false, then (GR) is untenable. Below I will suggest some reasons for doubt concerning this antecedent.

But Goldman's case against (GR) does not rest entirely on his doubts concerning reductionism; it involves as well a suggestive discussion of Elizabeth Fricker's view of testimony. Fricker writes: "the thesis I advocate...is that a hearer should always engage in some assessment of the speaker for trustworthiness. To believe what is asserted without doing so is to believe blindly, uncritically. This is gullibility” (365, citing Fricker 1994, p. 145). As Goldman notes, this position is entirely in keeping with the spirit of (GR). However, in a later paper, Fricker "appears to soften her claim," and Goldman seizes upon this softening:

...Fricker appears to soften her claim. She distinguishes between the "developmental” and "mature" phases of the reception of testimony. "Simply-trusted testimony plays an inevitable role in the causal process by which we become masters of our commonsense scheme of things" ([Fricker] 1995: 403). In other words, young children cannot be expected to monitor for defeating evidence while they are still acquiring the kinds of common-sense knowledge that can be used to defeat presumptions of trust. This softer position seems to me more plausible. Notice, however, that when it is applied to the educational context, it cuts against a universal application of the critical-thinking approach. Very young children, at least, should not be expected or trained to monitor a teacher's utterances for untrustworthiness. Teachers' statements can be justifiably 
believed via unsupported trust, and it is not unreasonable for the educational system to expect young children to accept such statements without first subjecting them to critical scrutiny (365).

There are several points to note concerning this argument. First: even if correct, it applies only to very young children, and is in this respect only a minimal 'softening' of Fricker's earliercited view. Fricker's 'developmental phase' is not demarcated very precisely in her discussion, but it seems beyond doubt that, depending on the precise demarcation in question, many even very young children are already in possession of a 'commonsense scheme of things.' It would be foolhardy to try to identify the precise age or developmental (sub)stage at which the child achieves this possession, but it seems clear that it occurs before, and certainly by, the kindergarten years. (Imagine conversations you have had with your three or four or five year old child, niece/nephew, or neighbor. Is it plausible that the child in question lacked 'our commonsense scheme of things'?) Goldman's point can and should be granted. It has little impact on the disagreement between us. The (GR) view remains (mainly) intact in the face of it. The point establishes only that 'very young children' cannot be expected to monitor testimonial reports for trustworthiness. If they are really very young, who would disagree?

Indeed, advocates of the (GR) position have typically embraced Goldman's point concerning very young children. Philosophers of education have routinely discussed it in the context of debate concerning indoctrination. In the 'developmental' phase, in which young children acquire a host of concepts and learn (e.g.) the meanings of words, the mechanics of reference, basic facts about the world, and other basic items which together make up their 'commonsense scheme of things,' they are not yet in a position to be critical. This has suggested to many theorists that parents and other educators have no choice but to indoctrinate very young children into that commonsense scheme of things - that indoctrination, in other words, is inevitable. The problem has seemed to many to be especially acute for advocates of (GR), since it suggests that young children must be indoctrinated into the relevant beliefs, attitudes and dispositions, and unreflectively master the relevant skills and abilities, in order to become critical thinkers - that they must, in short, be indoctrinated into critical thinking. This is a corner into which advocates of critical thinking are reluctant to be backed. Can they escape it?

All sides agree that children cannot begin their cognitive lives as critical thinkers. They must learn to be critical thinkers - they must acquire the relevant concepts, and develop the relevant beliefs, skills and abilities, and dispositions, values, and habits of mind, in the educational process of becoming critical thinkers. Whether this process requires indoctrination depends on one's account of indoctrination. Philosophical accounts of indoctrination have traditionally understood it in terms either of the aim or intention of the educator/indoctrinator, the method utilized by the educator/indoctrinator, or the content imparted to the student. These have in common that whether a student is a victim of indoctrination depends upon what has been called by Thomas F. Green her 'style of belief' : she has been indoctrinated to the extent that she has been led to hold beliefs in such a way that she cannot subject hers to critical evaluation. In such a case, the student has a non-evidential style of belief. However, she can acquire all the relevant concepts, beliefs, skills, abilities, dispositions, etc. associated with critical thinking in a way which does not produce such a style of belief. What she acquires, by means of nonindoctrinative educational processes, is, once acquired, open to critical assessment. In such a case, non-indoctrinative educational processes produce an evidential style of belief, and it is this which the advocate of (GR) prizes. In this way children can become critical thinkers without 
having to be indoctrinated into that status. ${ }^{-}$

As children do not begin their cognitive lives as critical thinkers, they do not begin those lives able to monitor testimony for trustworthiness - as Fricker and Goldman rightly insist, they must first acquire their 'commonsense scheme of things.' In the 'developmental phase,' accepting the testimony of others, without monitoring it for trustworthiness, is at least largely inevitable. Here (GR) is indeed inapplicable, as Goldman rightly notes. However, this is a quite minor restriction on the application of (GR), since the developmental phase is essentially completed at a quite early point in the typical child's education. Beyond that point - that is, for most of a child's education, and the whole of her adult life - (GR) is, for all Goldman has said, completely applicable.

There are some further points to make concerning Goldman's case that students, contrary to advocates of critical thinking, are at least sometimes justified in believing what their teacher tells them, even when they lack independent reason to trust them on that occasion.

1. It is central to Goldman's analysis that students often, perhaps typically, do not have testimony-independent reasons for trusting their teachers. I believe, to the contrary, that students typically do have such reasons. Students generally have a variety of independent (of testimony) reasons for trusting their teachers: Teachers are in positions of authority; they possess relevant academic credentials; they are treated as experts by their colleagues, administrators, and other adults (including the students' parents); etc. All this provides students with at least some nontestimony-based reasons for trusting their teachers. So the situation Goldman envisages, in which students have no non-testimony-based reasons for trusting their teachers, is much less common than might appear at first glance.

I have formulated the point in terms of students and teachers, but in fact it has application far beyond the educational context (although I cannot defend this broader point concerning the epistemology of testimony at length here). As Jonathan Adler (2002) argues, there is a wealth of indirect, background evidence for accepting as reliable (defeasibly, of course), without direct evidence of its reliability, the testimony of others. We all have lots of experience of such testimony (from strangers giving directions, from news reporters with whom we are not personally acquainted, from neighbors and friends, etc.); in the vast majority of cases such testimony proves trustworthy. If it didn't, our common practice of accepting testimony as reliable would be very different. The arguments Goldman advances against reductionism unduly ignore this vast repository of evidence we all have for the general reliability of testimony. (And it must again be noted that Goldman does not argue at length for the failure of reductionism and so of GR; as noted above, his argument rather is of the form: if reductionism fails, then GR fails as well. I believe that the vast quantity of background evidence available to all of us for the general reliability of testimony, pointed to by Adler, upends the antecedent of this conditional.)

2. Even if we reject my claim that the general reasons for trust in the educational context given above (position of authority; relevant academic credentials; treatment by parents and other adults; etc.) are good ones, other, more specific reasons are typically available. Consider, as an example, the algebra (or history) student. Let us suppose that on the first day of class the student has no independent reason to trust what the teacher tells her about the subject. But as the class proceeds, every day the student sees the teacher introducing material about which the student is ignorant, hears the teacher's explanations, observes the teacher answer her (and other students') questions, sees the teacher speak extemporaneously on tangents that (it is often apparent) were not part of the teacher's prepared remarks, etc. All this provides the student with testimonyindependent (defeasible) reasons for trusting the teacher's claims with respect to that subject 
matter. Consider: by the end of his first lecture in Introduction to Epistemology, don't his students have some testimony-independent reason to trust what Professor Goldman says about the conditions of knowledge or the history and character of the Gettier problem? In the same way, the algebra (or history) student has increasing testimony-independent reason for trusting her teacher's declarations concerning the subject matter at hand.

3. As noted above, it is important to be clear on which students we're discussing here. I agree with Goldman that very young children typically do not have testimony-independent reasons for trusting their teachers; among other reasons for this claim, they don't yet have a firm grasp of the relevant concepts. So I'm happy to grant the point with respect to very young children. But education goes far beyond very young children who don't yet have a grasp of the relevant concepts, exposure to relevant evidence, or the basic knowledge that is a large part of our 'commonsense scheme of things.' For older children, and adult students, there is virtually always such independent reason for trust, of the sorts already mentioned. And even for quite young children such independent reason is sometimes available. For example, my daughter, when in first grade, was impressed with a number trick (concerning adding nines) her teacher taught her; she could see intuitively that the trick worked in the sense that it gave the right answers. When she saw that, she had independent reason for trusting that teacher in matters arithmetical (at least). If so, a first grader can have testimony-independent reason for trusting her teacher. Consequently, even quite young students needn't rely on trust. Goldman's point is highly age- (and developmental stage-) sensitive: it is most plausible at very young ages, but quite implausible at intermediate and higher ages. $\frac{10}{-}$

\section{Conclusion}

I have argued that Goldman's claim that truth (rather than critical thinking) is the ultimate epistemic aim of education is problematic, as are his claims concerning the epistemic places of testimony and trust in education. Despite my disagreements with Goldman on these issues, I agree with him on the several specific matters noted at the outset. More important than these points of agreement/contention, in my view, is his taking these philosophical questions concerning education seriously. Goldman's work makes manifestly clear that epistemological reflections on education promise important philosophical insights, both for epistemology and for education. His discussions are important contributions to our broad theoretical understanding of the epistemology of education. Further work on these issues has enormous promise for the enhancement of the philosophy of education, as philosophers of education and epistemologists debate the desirability of conceiving the epistemological holy grail of education as truth, critical thinking, or something else. -11 I close by saluting Goldman, who has demonstrated the power of the philosophical insights that can be gleaned by applying the tools and theories of epistemology to the epistemological dimensions of education, and by encouraging other philosophers to join in the effort to shed philosophical light on the theory and practice of education. $\underline{12}$ 
Notes

$\underline{1}$ Happily, this situation is improving of late, as philosophers with increasing frequency address educational matters in their work. Well known contemporary figures, e.g. Martha Nussbaum (1997), Hilary Putnam (1993), and Richard Rorty (1990) have addressed philosophical issues concerning education. Amélie Rorty's collection Philosophers on Education (1998) contains the work of many other prominent philosophers. Israel Scheffler (e.g. 1965, 1989) has for many years addressed such issues. The Eastern Division of the American Philosophical Association (APA) has in recent years recognized philosophy of education as a 'special field,' and has created an Advisory Committee to the Program Committee in philosophy of education. Philosophy of education as an area of philosophy is enjoying a period of increased activity and perceived legitimacy in the broader philosophical community. This is, in my view, a wholly good and welcome development.

$\stackrel{2}{-}$ Unless otherwise noted, all page references in the text are to this book. For a detailed descriptive (and laudatory) review of its contents, see Siegel (2002).

3 In my (1988, p. 32) I argue that "critical thinking” is best understood as the "educational cognate" of rationality. I here assume this account of critical thinking, and so use "critical" and "rational" indifferently in the text. Obviously much more can and should be said about these key notions and their relationship than I can say here.

$\stackrel{4}{-}$ Although Goldman here equates them, philosophers of education often distinguish between education and schooling. I won't pursue this matter here.

$\underline{5}$ As it was during the general discussion at the APA symposium mentioned below.

$\underline{6}$ Tim Black insightfully objects that this appeal to the educational undesirability of "lucky true belief" is unfair to veritism, since the allegedly superior educational value of critical thinking to which I here appeal relies on critical thinking's general tie to truth (even though it leads away from truth in these sorts of cases). Black's objection may well be correct - as I grant below in pointing out the compatibility of the point made in the text with veritism's insistence that the value of justification lies in its instrumental tie to truth. Nevertheless, I think the case is suggestive of an epistemic value of critical thinking beyond that instrumental one. Thanks here to Black.

근 Here I am indebted to conversation with Jonathan Adler and Israel Scheffler.

$\stackrel{8}{-}$ I am indebted here to correspondence with Don Arnstine and Israel Scheffler.

9 There is of course much more to be said about all of this. For the fuller story, see Siegel 1988, ch. 5. The idea of "style of belief” originates, as far as I am aware, with Thomas F. Green (1971).

$\underline{10}$ Israel Scheffler has long emphasized the point that in teaching, reasons must be age-sensitive: 
a good reason - i.e. a reason which justifies, which provides an adequate tether - for a $4^{\text {th }}$-grader might not but need not meet the standard of goodness that reasons must meet for us (cf. Scheffler 1965, pp. 57-8).

$\underline{11}$ For example, Catherine Z. Elgin suggests in her (1999), a version of which was presented at the APA session mentioned in the next note, that understanding is the proper epistemic aim of education. See also her (1996).

$\underline{12}$ This paper began as a commentary on papers presented by Catherine Z. Elgin and Alvin Goldman at an invited symposium on 'Epistemology and Education' at the Eastern Division APA meeting in December 1998. I am grateful to the APA for organizing the session and inviting my participation, to Goldman and Elgin for their incisive criticisms of my commentary on that occasion, and to the audience for their excellent comments and suggestions. A more recent version was presented at California State University, Fresno in May 2002; I am grateful to Otávio Bueno for organizing that event and to Bueno and the other participants, esp. Tim Black, for their challenging objections and illuminating suggestions. Special thanks to Israel Scheffler, who proposed and chaired the APA session.

\section{References}

Adler, J. 2002. Belief's Own Ethics. Cambridge: MIT Press.

BonJour, L. 1985. The Structure of Empirical Knowledge. Cambridge: Harvard University Press.

Elgin, C. Z. 1996. Considered Judgment. Princeton: Princeton University Press.

Elgin, C. Z. 1999. “Epistemology’s Ends, Pedagogy’s Prospects,” Facta Philosophica 1: 39-54.

Firth, R. 1981. "Epistemic Merit, Intrinsic and Instrumental,” Proceedings and Addresses of the American Philosophical Association 55: 5-23.

Fricker, E. 1994. “Against Gullibility.” In B.K. Matilal and A.Chakrabarti (eds.), Knowing from Words, 125-161. Dordrecht: Kluwer.

Fricker, E. 1995. “Telling and Trusting: Reductionism and Anti-Reductionism in the Epistemology of Testimony,” Mind 104: 393-411.

Goldman, A. I. 1998. “Education and Social Epistemology.” In Rorty (1998): 439-450.

Goldman, A. I. 1999. Knowledge in a Social World. Oxford: Oxford University Press.

Green, T. F. 1971. The Activities of Teaching. New York: McGraw-Hill. 
Nussbaum, M. 1997. Cultivating Humanity: A Classic Defense of Reform in Liberal Education. Cambridge: Harvard University Press.

Putnam, H., and Putnam, R. A. 1993. “Education and Democracy,” Educational Theory 43: 361376.

Rescher, N. 1988. Rationality: A Philosophical Inquiry into the Nature and the Rationale of Reason. Oxford: Clarendon Press of Oxford University Press.

Rorty, A. O. (ed.). 1998. Philosophers on Education: New Historical Perspectives. London: Routledge.

Rorty, R. 1990. “The Dangers of Over-Philosophication: Reply to Arcilla and Nicholson,” Educational Theory 40: 41-45.

Scheffler, I. 1965. Conditions of Knowledge. Glenview, Illinois: Scott, Foresman and Company.

Scheffler, I. 1989. Reason and Teaching. Indianapolis: Hackett. Originally published in 1973 by Routledge \& Kegan Paul.

Siegel, H. 1988. Educating Reason: Rationality, Critical Thinking, and Education. London: Routledge.

Siegel, H. 1997. Rationality Redeemed? Further Dialogues on an Educational Ideal. New York: Routledge.

Siegel, H. 1999. “Knowledge, Truth and Education.” In D. Carr (ed.), Education, Knowledge and Truth: Beyond the Postmodern Impasse, 19-36. London: Routledge.

Siegel, H. 2002. "Review of Alvin I. Goldman, Knowledge in a Social World,” Argumentation 16: 369-382. 